\title{
Фактори ризику та профілактика тромбозу у пацієнтів із COVID-19
}

\author{
О.О. Ханюков, Л.В. Сапожниченко, О.С. Калашникова, О.В. Соміло, Є.О. Охотнік \\ Державний заклад «Дніпропетровська медична академія Міністерства охорони здоров'я України», Дніпро, Україна
}

Анотація. У статті представлений огляд літератури дослідження факторів ризику та профілактики тромбозу при COVID-19. Kоагулопатія при COVID-19 характеризується підвищенням рівнів фібриногену та D-димеру, помірною тромбоцитопенією та незначним підвищенням протромбінового часу. Основними факторами ризику, що підвищують вірогідність виникнення тромбоемболічних подій, встановлено похилий вік (>60 років), чоловічу стать, артеріальну гіпертензію, цукровий діабет та ожиріння. Для стандартної стратифікації ризику тромбозу в сучасних умовах необхідно користуватися модифікованою шкалою IMPROVE, яка $\epsilon$ найбільш оптимальною для застосування у пацієнтів із COVID-19 та враховує всі показники для розрахунку ризику тромбоемболії у цих хворих. Для попередження тромбозу у пацієнтів із COVID-19 показане застосування низькомолекулярних гепаринів. Прийом антикоагулянтів після виписки зі стаціонару може бути розглянутий за наявності високого ризику тромбозу та низького ризику кровотечі. Питання щодо прийому антиагрегантів з метою зниження ризику виникнення тромбозу залишається відкритим та потребує подальшого вивчення. Ключові слова: COVID-19, тромбоз, фактори ризику, профілактика, шкали ризику.

\section{Фактори ризику тромбозу}

\section{у пацієнтів із COVID-19}

Пандемія COVID-19 - одна з найактуальніших та найбільш обговорюваних проблем сьогодення. За даними Університету Джона Хопкінса (Johns Hopkins University), США, станом на 26.04.2021 р. у світі налічується 147298815 підтверджених випадків захворювання, серед яких 3111587 - летальні. Серед країн, які найбільше постраждали, - США (32 078 229), Індія (17 313 163), Бразилія (14 340787 випадків). Не обійшло стороною й Україну, де, за даними Міністерства охорони здоров'я, налічується 2084384 випадків захворювання [1].

Захворювання COVID-19, спричинене коронавірусом SARS$\mathrm{CoV}-2$, характеризується посиленою запальною реакцією з боку всіх систем організму людини, яка, в свою чергу, може призвести до таких серйозних ускладнень, як гострий респіраторний дистрес-синдром (ГРДС), сепсис, коагулопатія та смерть у частки пацієнтів [2]. У цій публікації ми зупинимося саме на порушеннях системи гемостазу, оскільки вони широко розповсюджені у пацієнтів із COVID-19 та асоційовані з високою смертністю хворих.

Коагулопатію визначають у близько 50\% пацієнтів із тяжким перебігом COVID-19. Вона відрізняється від коагулопатії при синдромі дисемінованого внутрішньосудинного згортання крові (ДВЗ) підвищенням рівня фібриногену (при класичному синдромі ДВЗ його рівень зазвичай <1 г/л) з помірною тромбоцитопенією (кількість тромбоцитів при синдромі ДВ3 зазвичай $<50 \cdot 10^{9} /$ л) та незначним підвищенням протромбінового часу (ПЧ) до 1-2 с (на відміну від >3-6 с при синдромі ДВ3) [3]. У пацієнтів із COVID-19 порівняно $з$ хворими із ГРДС без COVID-19 значно частіше розвиваються тромбоемболічні ускладнення (ТЕУ), переважно тромбоемболія легеневої артерії (ТЕЛА) (11,7 та 2,1\% відповідно) [3]. За результатами метааналізу поширеність ТЕЛА становить близько 30\% у паці$\epsilon$ тів із тяжким перебігом COVID-19 [4]. Це ускладнення відмічають у 7-8 разів частіше у пацієнтів із COVID-19, ніж у хворих з іншими респіраторними інфекціями. Наприклад, гістологічний аналіз легеневих судин показав, що широко розповсюджений тромбоз у 9 разів частіше виникає у хворих на COVID-19, ніж у пацієнтів із грипом H1N1 [5]. Крім цього, через наявність спільних симптомів у COVID-19 та ТЕЛА і складність діагностики останньої у цих пацієнтів цей відсоток може бути значно вищим.

Багато уваги приділяють дослідженню ризику венозного тромбозу та ТЕЛА, однак існують випадки артеріального тромбозу, який також асоціюється з поганим прогнозом. Серед 3334 госпіталізованих пацієнтів із COVID-19 у 4 клініках США частота артеріального тромбозу становила 11,1\% [6]. У дослідженнях, проведених у Франції, Італії та Іспанії, цей показник становив $5,6 \%[7,8]$. Така частота та небезпека цих ускладнень роблять вивчення механізмів та факторів ризику розвитку тромбозу у пацієнтів із COVID-19 вкрай актуальним завданням.

Крім загальноприйнятих механізмів розвитку тромбозу при інфекційних захворюваннях, $\epsilon$ й специфічні зміни, такі як цитокіновий шторм, який відмічають у хворих із COVID-19 та $\epsilon$ однією з основних причин розвитку розладів системи гемостазу [9]. Однак остаточні патофізіологічні механізми змін гемостазу у пацієнтів із тяжким перебігом COVID-19 досі незрозумілі.

Для ефективного менеджменту пацієнтів та своєчасних превентивних заходів щодо тромбозу необхідне розуміння факторів ризику тромбозу у пацієнтів із COVID-19, тобто того, які саме пацієнти потребують особливої уваги з точки зору можливого порушення гемостазу. Результати досліджень вказують на те, що факторами ризику TEУ у пацієнтів із COVID-19є похилий вік (>60 років), чоловіча стать, іммобілізація та наявність супутніх захворювань. Наявність в анамнезі пацієнтів із COVID-19 хронічних захворювань, таких як цукровий діабет, ожиріння та артеріальна гіпертензія, підвищує ризик розвитку ТЕУ [10-13]. Ожиріння та тютюнопаління визначені як важливі фактори ризику тромбозу глибоких вен (ТГВ) у великому проспективному дослідженні A.G. Holst та співавторів (2010) за участю >18 тис. пацієнтів [14]. У дослідженні N. Benito та співавторів (2020) вік пацієнтів із тяжким перебігом COVID-19 та ТЕУ становив $\geq 60$ років [15].

Представляє інтерес інформація про зв'язок групи крові пацієнтів із ризиком TEУ. У дослідженні S.Z. Marcos та співавторів (2020) встановлено, що хворі на COVID-19 із III групою крові мають вищий ризик ТЕУ, ніж пацієнти з іншими групами крові. Проаналізовано дані 226 пацієнтів (середній вік 70,9 року) і встановлено статистично значущий зв'язок між ТЕУ та надходженням хворих у відділення інтенсивної терапії з певною групою крові. У пацієнтів з III групою крові ТЕУ відмічали на 28,6\% частіше. Рівень D-димеру більше підвищувався у пацієнтів із III, ніж I групою крові. Рівень фібриногену більшою мірою підвищувався у пацієнтів із IV та III, ніж I групою крові [16].

\section{Маркери тяжкого перебігу та тромбозу у пацієнтів із COVID-19}

Особливу увагу звертають на себе маркери, які вказують на тяжкий перебіг інфекційного захворювання та високий ризик розвитку тромбозу у пацієнтів. При імунологічному дослідженні пацієнтів із COVID-19 виявлено, що такі прозапальні цитокіни, як інтерлейкін-6, -17А та фактор некрозу пухлини-а, підвищені у більшості пацієнтів із тяжким перебігом захворювання $[17,18]$.

У дослідженні, проведеному в Китаї, продемонстровано наявність антикардіоліпінових антитіл та антитіл до $\beta_{2}$-глікопротеїну I у пацієнтів із ішемічним інсультом [19], а серія випадків у Франції 
виявила позитивний вовчаковий антикоагулянт у 25 із 56 (45\%) пацієнтів із підтвердженим COVID-19 [20]. При цьому зазначено, що роль наявності антифосфоліпідних антитіл ще не визначена, оскільки відомо, що їх виявляють у пацієнтів і з іншими гострими інфекціями.

Сьогодні виділяють маркери, які вказують на високий ризик тяжкого перебігу COVID-19 та розвиток тромбозу. У пацієнтів відмічають лімфопенію, лейкоцитоз, підвищені рівні аланінамінотрансферази, лактатдегідрогенази, високочутливого тропоніну I, сечовини та креатиніну у крові, подовження ПЧ, зниження концентрації фібриногену, підвищення значень прокальцитоніну, високі значення D-димеру [13].

Особливу увагу приділяють визначенню в крові пацієнтів рівня D-димеру. Значення цього показника пов'язане з критичним перебігом захворювання та вищою смертністю. Визначено, що значення D-димеру вищі у пацієнтів із тяжкою формою COVID-19, ніж із легким перебігом, тому хворим із значним підвищенням рівня D-димеру ( $y \geq 3-4$ рази) рекомендується госпіталізація, навіть за відсутності вираженої симптоматики [10]. Ретроспективне дослідження W.J. Guan та співавторів (2020) ( $n=1099)$ встановило зв'язок між тяжкістю перебігу COVID-19 та високим рівнем D-димеру. Рівень D-димеру $\geq 0,5$ мг/л відмічали у $46,4 \%$ пацієнтів та у $60 \%$ з них розвинулися тяжкі прояви захворювання [21]. Інше ретроспективне дослідження $(\mathrm{n}=183)$ встановило, що рівень D-димеру у пацієнтів із тяжким перебігом захворювання майже у 3,5 раза вищий, ніж у хворих із легким чи середньої тяжкості перебігом [22]. Крім цього, зазначено, що D-димер $\epsilon$ маркером відкладення фібрину у легенях. Досвід іспанських лікарів встановив, що хворі, в яких виявлено високі рівні D-димеру та C-реактивного білка, частіше потребували госпіталізації та переведення на штучну вентиляцію легень [15].

\section{Профілактика тромбозу у хворих із COVID-19}

Сьогодні проблема профілактики тромбоемболічних подій у хворих із COVID-19 залишається надзвичайно важливим питанням [23], як і ГРДС при SARS-CoV-2-інфекції, асоційований із артеріальними та венозними ускладненнями. У цій публікації ми також хотіли би зупинитися на основних принципах профілактики тромбозу як тяжкого ускладнення COVID-19.

Хворим із високим ризиком розвитку ТЕУ слід проводити ранню профілактику цих подій, при цьому значення активованого часткового тромбопластинового часу (АЧТЧ) не повинно бути протипоказанням до застосування антикоагуляційних методів лікування та профілактики у пацієнтів із COVID-19. Антикоагулянти внесені у протоколи лікування більшості країн світу у якості обов'язкових препаратів з метою профілактики та лікування ТЕУ у хворих на COVID-19 в умовах стаціонару. Зазначено, що дорослі пацієнти, які госпіталізовані з діагнозом COVID-19, повинні отримувати ці препарати, якщо ризик кровотечі не перевищує ризик виникнення тромбозу. У якості профілактики тромбозу рекомендується застосовувати низькомолекулярні гепарини (НМГ), при цьому не рекомендується застосування нефракціонованого гепарину (НФГ) [3]. На сьогодні $\epsilon$ дані, що підтверджують розвиток резистентності до НФГ у пацієнтів із COVID-19. Дослідження D. White (2020), проведене у відділенні інтенсивної терапії, показало, що 80\% хворих потребували НФГ у дозі >35 тис. од. на добу. Причини стійкості до гепарину не виявлено, однак вчені висувають гіпотезу, що негативно заряджений гепарин взаємодіє з позитивно зарядженими білками плазми крові, деякі з них вступають у взаємодію як реагенти гострої фази і конкурують за зв'язування гепарину, що обумовлює таку стійкість до гепарину. Також автори вказують, що цей факт не корелює з підвищенням рівня фібриногену чи фактором згортання крові VIII або зі зниженим рівнем антитромбіну [24].

Дослідження A. Cuker, F. Peyvandi (2021) визначило, що найвищий ризик розвитку тромбозу зафіксовано у пацієнтів, які заходяться у відділені реанімації, при цьому зазначається, що тромбоемболічні події можуть виникати у пацієнтів із легким перебігом захворювання приблизно у 2,6\% випадків. У більшості пацієнтів відмічають такі зміни лабораторних показників: під- вищення рівня протромбіну, збільшення кількості тромбоцитів (348 тис./мкл), підвищення рівня фібриногену (середнє значення 680 мг/дл, діапазон 234-1344 мг/дл), підвищення рівня D-димеру (середнє значення 4877 нг/мл, діапазон 1197-16954 нг/мл), підвищення активності фактора згортання крові VIII (в середньому 297 Од./дл), підвищення рівня антигенів фактора фон Віллебранда (середнє значення 529, діапазон 210-863), що є маркером пошкодження ендотелію судин, зниження рівня антитромбіну та вільного протеїну S, незначне підвищення рівня протеїну C [25].

3 огляду на вищезазначене, сучасні протоколи ведення стаціонарних хворих із COVID-19 рекомендують оцінити дані загального аналізу крові з акцентом на рівень тромбоцитів, коагулограми (ПЧ, АЧТЧ), рівня фібриногену, D-димеру (високі значення визначають несприятливий прогноз). Повторна переоцінка цих показників необхідна щодня або рідше; це перш за все залежить від тяжкості перебігу захворювання. Пацієнтам, які лікуються в амбулаторних умовах, не потрібно проводити регулярне тестування для оцінки показників системи згортання крові.

Крім оцінки загальних факторів ризику тромбозу, необхідно пам'ятати про стандартну стратифікацію ризику тромбозу за шкалами. Існує велика кількість шкал для оцінки ризику TEУ: Wells (визначення вірогідності ТГВ нижніх кінцівок), Padua (оцінка ризику розвитку ТГВ нижніх кінцівок та/або ТЕЛА у госпіталізованих хворих нехірургічного профілю), Caprini, IMPROVE, яку можна застосовувати для хворих із COVID-19 (табл. 1). Велике рандомізоване контрольоване дослідження APEX (Acute Medically III VTE Prevention With Extended Duration Betrixaban Study) встановило, що підвищений рівень D-димеру може використовуватися для відбору хворих, які потребують профілактики ТЕУ: пацієнти, госпіталізовані з гострим нехірургічним захворюванням (серцева недостатність, дихальна недостатність, інфекційні захворювання, ревматичні захворювання, ішемічний інсульт) і мали підвищений рівень D-димеру ( $\geq 2$ рази від верхньої межі норми) отримали позитивний результат від тривалого прийому антикоагулянтів для профілактики тромбозу [27]. На підставі даних цього дослідження запропонована модифікована шкала IMPROVE, в якій додано рівень D-димеру як фактор ризику виникнення венозного тромбозу.

Таблиця 1 Шкала оцінки ризику ТГВ/ТЕЛА у нехірургічних пацієнтів, модифікована шкала IMPROVE (адаптовано 3 [26])

\begin{tabular}{lc}
\hline \multicolumn{1}{c}{ Фактор ризику } & Бали \\
\hline Венозна тромбоемболія в анамнезі & 3 \\
\hline Наявна тромбофілія & 2 \\
\hline Парез або параліч нижніх кінцівок & 2 \\
\hline Злоякісне новоутворення в анамнезі & 2 \\
\hline Рівень D-димеру у $\geq 2$ рази перевищує верхню межу норми & 2 \\
\hline Госпіталізація у відділення інтенсивної терапії & 1 \\
\hline Іммобілізація $\geq 1$ дня & 1 \\
\hline Вік $>60$ років & 1 \\
\hline
\end{tabular}

При сумі балів $\geq 2$ ризик венозних ТЕУ вважають підвищеним.

Але на сьогодні стратегії скринінгу ТГВ або ТЕЛА у пацієнтів із COVID-19 викликають багато питань. В умовах відділення інтенсивної терапії перебування на штучній вентиляції легень у положенні лежачи значно ускладнює проведення ретельного ультрасонографічного обстеження. Різні шкали оцінки претестової імовірності ТЕЛА можуть бути некоректними через значно вищу частоту ТГВ порівняно з іншими групами пацієнтів. Використання рівня D-димеру також виявляється малоінформативним. Згідно 3 рекомендаціями Європейського товариства променевої терапії European Society of Radiology - ESR), Європейського товариства з торакальної візуалізації (European Society of Thoracic Imaging ESTI) та Європейського товариства кардіологів (European Society of Cardiology - ESC) комп'ютерну томографію з контрастною речовиною необхідно проводити для виключення ТЕЛА у пацієнтів із COVID-19, коли дихальна недостатність не може бути пояснена результатами звичайної комп'ютерної томографії $[28,29]$. Сьогодні клініцисти можуть використовувати рекомендації щодо призначення антикоагулянтів у госпіталізованих пацієнтів від Американської 
колегії лікарів, що спеціалізуються на захворюваннях органів грудної порожнини (American College of Chest Physicians - ACCP), та Міжнародного товариства з тромбозу та гемостазу (International Society on Thrombosis and Haemostasis - ISTH). Обидві організації не рекомендують проводити рутинну профілактику тромбозу у пацієнтів, яких не госпіталізовано. У госпіталізованих пацієнтів, які не перебувають у критичному стані, ISTH пропонує застосовувати профілактичні дози НМГ, а АССР рекомендує НМГ у профілактичних дозах або фондапаринукс (інгібітор активованого фактора X). Пацієнтам у критичному стані АССР рекомендує НМГ у профілактичних дозах, а ISTH - НMГ у профілактичній дозі або половину терапевтичної дози для пацієнтів із високим ризиком (табл. 2).

За результатами ретроспективного дослідження, проведеного в Нью-Йорку ( $n=2773)$, встановлено, що застосування антикоагулянтів пов'язане з вищим рівнем виживання в інтубованих пацієнтів (71\% проти 37\% тих, хто не отримував антикоагулянти) [31]. Інше ретроспективне дослідження (449 осіб із тяжким перебігом COVID-19) встановило високий рівень виживання у паці$\epsilon$ нтів, які отримували еноксапарин у дозі 40-60 мг 1 раз на добу, особливо у хворих із високими значеннями D-димеру [32].

В одному невеликому дослідженні $(n=16)$ хворі отримували надропарин у високих профілактичних дозах разом із клопідогрелем, при цьому не повідомлялося про жодний випадок ТЕЛА, але невелика кількість пацієнтів та відсутність контрольної групи обмежують використання цих даних на практиці [33]. Дози препаратів у госпіталізованих хворих із COVID-19:

- еноксапарин: при кліренсі креатиніну >30 мл/хв 40 мг 1 раз на добу, 15-30 мл/хв - 30 мг 1 раз на добу;

- далтепарин - 5000 од. 1 раз на добу;

- надропарин: пацієнтам із масою тіла $\leq 70$ кг в дозі 3800 або $4000,>70$ кг - 5700 од. анти-фактора Ха 1 раз на добу; у деяких випадках застосовують дози до 50 од. анти-фактора Ха/ кг кожні 12 год;

- тинзапарин - 4500 од. анти-фактора Ха 1 раз на добу;

- фондапаринукс по 2,5 мг 1 раз на добу [25].

Пацієнтам із кліренсом креатиніну $<15$ мл/хв або із замісною нирковою терапією рекомендовано застосовувати НФГ. За наявності задокументованої венозної тромбоемболії необхідно призначити антикоагулянти в повній дозі (наприклад еноксапарин по 40 мг 2 рази на добу або по 1 мг/кг маси тіла кожні 12 год) за відсутності протипоказань, таких як активна кровотеча або масивна кровотеча протягом останніх 24-48 год, індукована гепарином тромбоцитопенія в анамнезі. У разі виникнення індукованої гепарином тромбоцитопенії рекомендується призначення фондапаринуксу у якості альтернативного препарату (табл. 3).

Існують також випадки тромбозу, незважаючи на терапію антикоагулянтами. Ведення таких пацієнтів потребує мультидисциплінарного підходу. У такому разі слід звернути увагу на комплаєнс, дозу, всмоктування препарату та можливі лікарські взаємодії. Також необхідно виключити тромбофілію та антифосфоліпідний синдром. Якщо після ретельної мультидисциплінарної оцінки не виявлено вищезазначених причин, змінюють режим або тип антикоагулянтної терапії. У разі тромбозу при прийомі пероральних антикоагулянтів прямої дії переходять на лікування еноксапарином. При виникненні ТЕУ на фоні лікування еноксапарином може бути ефективним перехід від дози 1 раз на добу (1,5 мг/кг/добу) на 2 рази на добу (1 мг/кг маси тіла 2 рази на добу). У разі неефективності терапії варфарином після ретельної оцінки міжнародного нормалізованого відношення та часу його утримання у терапевтичному діапазоні можливий перехід на пероральні антикоагулянти прямої дії або НМГ.

Детальний алгоритм ведення пацієнтів у стаціонарі наведено на рисунку.

\section{Профілактика тромбозу у пацієнтів після виписки зі стаціонару}

Хворі на COVID-19, у яких визначено ТЕЛА, потребують прийому антикоагулянтів протягом щонайменше 3 міс. Пацієнти, в яких не діагностували ТЕЛА, також потребують проведення тривалої тромбопрофілактики після виписки з лікарні при недавньому хірургічному втручанні або травмі за умови відсутності високого ризику розвитку кровотечі. Тривала тромбопрофілактика також показана всім пацієнтам, які отримували профілактичну терапію НМГ під час госпіталізації та за наявності ризику за модифікованою шкалою IMROVE 2-3 бали з підвищенням рівня D-димеру під час госпіталізації >2 норм (>1 мкг/мл) або ризику за модифікованою шкалою IMROVE $\geq 4$ бали. Варіантом профілактичного засобу після виписки $є$ ривароксабан в дозі 10 мг на добу протягом 31-39 днів [34].

Пацієнтам без факторів ризику не рекомендується профілактика тромбозу після виписки зі стаціонару. Так, в результаті спостереження за станом виписаних з лікарні після інфікування

Таблиця 2 Актуальні рекомендації з профілактики венозної тромбоемболії у госпіталізованих пацієнтів із COVID-19 (адаптовано 3 [30])

\begin{tabular}{lll}
\multirow{2}{*}{ Пацієнт } & \multicolumn{1}{c}{ Ааблиця 2 АссP } & \multicolumn{1}{c}{ Рекомендації } \\
\cline { 2 - 3 } & \multicolumn{1}{c}{ АSTH } \\
\hline Критичний стан & НМГ у профілактичній дозі & НМГ у профілактичній дозі; половина терапевтичної дози НМГ може бути надана, якщо пацієнт високого ризику \\
\hline Некритичний стан & НМГ у профілактичній дозі або фондапаринукс & НМГ у профілактичній дозі \\
\hline Після виписки & Довготривала профілактика не рекомендована & $\begin{array}{l}\text { НМГ/оральні антикоггулянти прямої дії до } 30 \text { днів може бути розглянутий при високому ризику тромбозу та } \\
\text { низькому ризику кровотечі }\end{array}$ \\
\hline Негоспіталізований & Рутинна профілактика не рекомендована & Рутинна профілактика не рекомендована \\
\hline
\end{tabular}

Таблиця 3 Дози парентеральних антикоагулянтів (адаптовано 3 [25])

\begin{tabular}{|c|c|}
\hline Препарат & Дозування \\
\hline НФГ & $\begin{array}{l}\text { Профілактика: підшкірно } 5000 \text { оД 2-3 рази на добу } \\
\text { Лікування: початкова доза при венозних ТЕУ — внутрішньовенно болюсно } 80 \text { 0Д/кг маси тіла (максимально } 5000 \text { оД) }\end{array}$ \\
\hline $\begin{array}{l}\text { Далтепарин (протипоказаний при вираженій } \\
\text { нирковій недостатності) }\end{array}$ & $\begin{array}{l}\text { Профілактика: підшкірно } 5000 \text { М0 } 1 \text { раз на добу } \\
\text { Лікування: підшкірно } 100 \text { М0/кг } 2 \text { рази на добу }\end{array}$ \\
\hline $\begin{array}{l}\text { Надропарин (протипоказаний при вираженій } \\
\text { нирковій недостатності) }\end{array}$ & Профілактика: підшкірно 3800 M0 (0,4 мл) 1 раз на добу при масі тіла $\leq 70$ кг або 5700 М0 (0,6 мл) 1 раз на добу при масі тіла >70 кг \\
\hline $\begin{array}{l}\text { Еноксапарин (протипоказаний при вираженій } \\
\text { нирковій недостатності) }\end{array}$ & $\begin{array}{l}\text { Профілактика: підшкірно } 4000 \text { М0 (40 мг) } 1 \text { раз на добу* } \\
\text { Лікування: підшкірно } 100 \text { МО (1мг)/кг маси тіла } 2 \text { рази на добу, при кліренсі креатиніну 15-30 мл/хв — така сама доза, але } 1 \text { раз на добу }\end{array}$ \\
\hline $\begin{array}{l}\text { Фондапаринукс (протипоказаний при вираженій } \\
\text { нирковій недостатності) }\end{array}$ & $\begin{array}{l}\text { Профілактика: підшкірно 2,5 мг } 1 \text { раз на добу } \\
\text { Лікування: } 5 \text { мг } 1 \text { раз на добу при масі тіла до } 50 \text { кг; } \\
7,5 \text { мг } 1 \text { раз на добу при масі тіла 50-100 кг; } \\
10 \text { мг } 1 \text { раз на добу при масі тіла >100 кг }\end{array}$ \\
\hline
\end{tabular}

*При кліренсі креатиніну 15-30 мл/хв можна розглянути зниження дози до 3000 М0 (30 мг) 1 раз на добу, при вираженому ожирінні можна розглянути підвищення дози до 4000 Мо (40 мг) 2 рази на добу. 


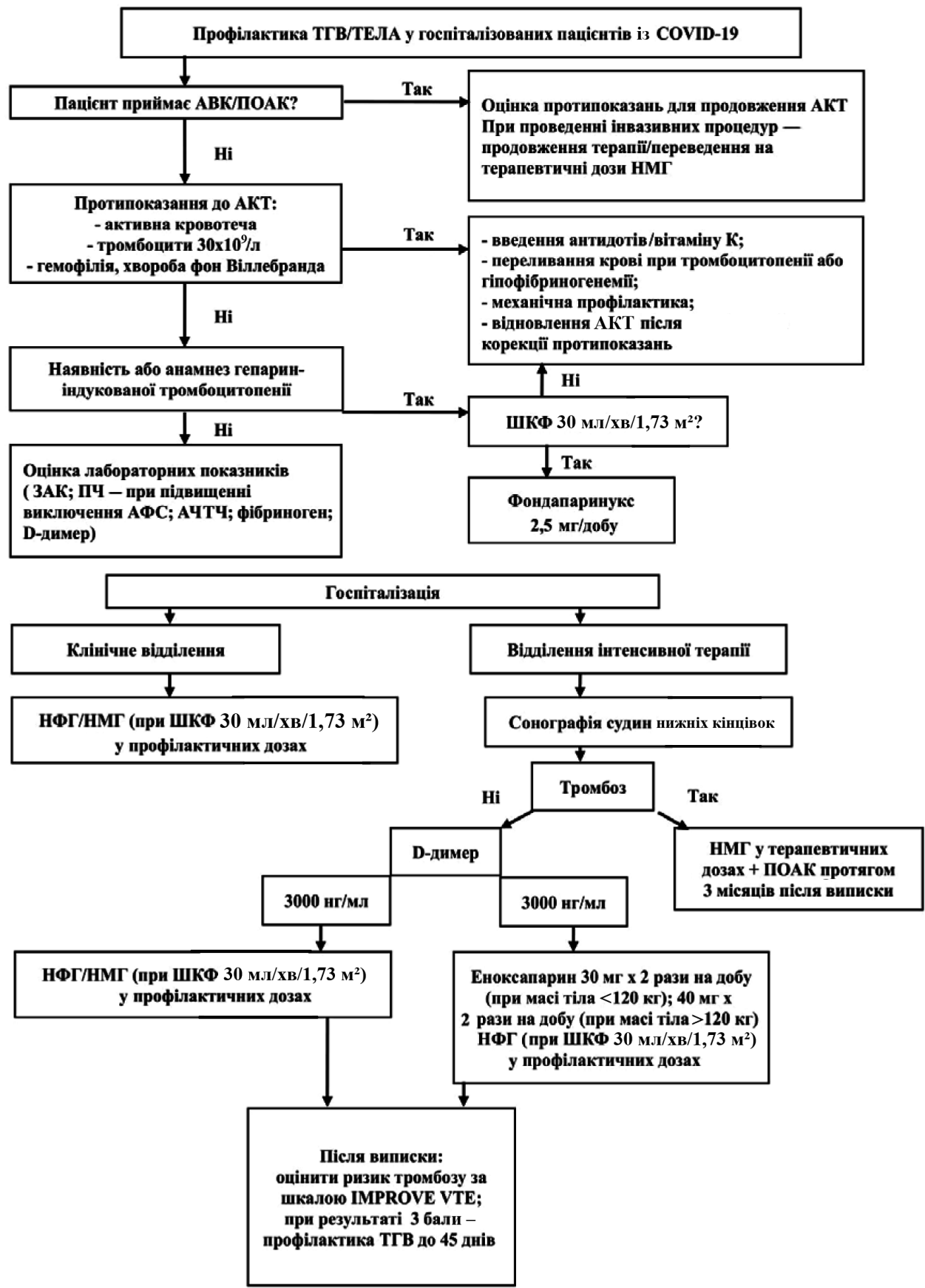

АВК/ПОАК — антагоністи вітаміну К/прямі оральні антикоагулянти; АКТ — антикоагулянтна терапія; ЗАК — загальний аналіз крові; АФС — антифосфоліпідний синдром; ШКФ — швидкість клубочкової фільтрації.

SARS-CoV-2 ( $\mathrm{n}=1877)$, які не застосовували тромбопрофілактичні засоби, ТЕЛА діагностовано лише у 9 (0,48\%) пацієнтів. Крім того, виявлено, що госпіталізація з приводу COVID-19 не підвищує ризик ТЕЛА після виписки зі стаціонару порівняно з госпіталізацією з приводу інших захворювань [35]. Інше дослідження показало, що серед 163 пацієнтів із підтвердженим COVID-19, які не отримували антикоагулянти, загальна частота тромбозу, включаючи артеріальні та венозні події, на 30-й день після виписки зі стаціонару становила 2,5\% [36].

\section{Профілактика тромбозу}

\section{в амбулаторних умовах}

На сьогодні доказова база щодо частоти ТЕУ в амбулаторних пацієнтів із COVID-19 відсутня, тож невідомо, чи потребують такі пацієнти рутинної тромбопрофілактики. Винятками $\epsilon$ окремі випадки $з$ наявністю факторів ризику тромбозу: ТЕЛА в анамнезі, травма, тривала іммобілізація.
У якості профілактики тромбозу рекомендовано застосовувати ривароксабан у дозі 10 мг/добу протягом 31-39 днів. Але на сьогодні результати рандомізованих досліджень, що стосуються тромбопрофілактики у амбулаторних хворих із COVID-19, ще не опубліковані. Детальна інформація щодо менеджменту пацієнтів із COVID-19-асоційованою гіперкоагуляцією наведена у табл. 4.

\section{Антиагреганти при COVID-19}

Ацетилсаліцилову кислоту рекомендовано призначати хворим із COVID-19 після отримання результатів дослідження, проведеного в Eastern Virginia Medical School [37]. Tакож University of Maryland School of Medicine вивчали ефективність ацетилсаліцилової кислоти у пацієнтів із COVID-19 ( $n=412)$. Визначено, що прийом ацетилсаліцилової кислоти асоціювався з низьким ризиком переведення пацієнтів на штучну вентиляцію легень (35,7\% у групі прийому ацетилсаліцилової кислоти проти 48,4\% у групі, яка не приймала ацетилсаліцилову кислоту; $\mathrm{p}=0,03)$. Однак не встановлена 
Таблиця 4 Короткий довідник оцінки та менеджменту при гіперкоагуляції, пов'язаній із COVID-19 (адаптовано з [25])

\begin{tabular}{ll}
\hline Стаціонарні хворі & \multicolumn{1}{c}{ Оцінка та моніторинг } \\
\hline Амбулаторні хворі & Щоденне визначення ПЧ, АЧТЧ, фібриногену, D-димеру \\
\hline Аномальні результати коагулограми & Микенеджмент \\
\hline Профілактика венозної тромбоемболії & Профілактичні дози антикоагулянтів для усіх госпіталізованих коггулограми не рекомендоване \\
& Половинна або повна терапевтична доза антикоагулянтів для критично хворих, наприклад у відділенні інтенсивної терапії \\
& Можливе продовження тромбопрофілактики після виписки \\
& Можлива тромбопрофілактика у деяких амбулаторних хворих \\
\hline Лікування венозної тромбоемболії & Повна терапевтична доза антикоагулянтів для діагностованої або можливої венозної тромбоемболії \\
& Лікування у стаціонарі за стандартними протоколами \\
& Продовжувати тривалу тромбопрофілактику після виписки \\
& Резервні фібринолітичні препарати (активатори плазміногену тканинного типу) для ТГВ при виникненні загрози для кінцівки, масивній ТЕЛА, \\
& Гострому порушенні мозкового кровообігу або гострому інфаркті міокарда \\
\hline
\end{tabular}

кореляція між прийомом ацетилсаліцилової кислоти та зниженням внутрішньолікарняної смертності [38]. Дослідження JJ. DiNicolantonioa, J. Barroso-Arandab (2020) вказує на можливість застосування пентоксифіліну та дипіридамолу у якості препаратів, що чинять антитромботичну дію, підвищуючи чутливість А2А-рецепторів до позаклітинного аденозину [39]. Але питання щодо прийому антиагрегантів з метою зниження ризику виникнення тромбозу залишається відкритим і потребує подальшого вивчення.

\section{Кровотеча}

Кровотеча не $\epsilon$ характерним проявом COVID-19; основною причиною цього ускладнення $\epsilon$ прийом антикоагулянтів. Госпіталізовані пацієнти з COVID-19, які отримують антикоагулянтну або антитромбоцитарну терапію у зв'язку з основним захворюванням, повинні продовжувати лікування, якщо не виникне значна кровотеча або тромбоцитопенія (<30·10\%/л). У свою чергу, підхід до лікування кровотечі подібний до такого в осіб без COVID-19 і може включати відміну антикоагулянтів та/або припинення лікування, введення антидотів (андексанет альфа при лікуванні ривароксабаном або апіксабаном, ідаруцизумаб - при застосуванні дабігатрану, цирапарантаг - при лікуванні НФГ, НМГ або інгібіторами факторів ІІа та Ха, вітамін К — при застосуванні варфарину, переливання крові - при тромбоцитопенії або гіпофібриногенемії) [34].

\section{Висновки}

1. Захворювання COVID-19, спричинене новим штамом вірусу SARS-CoV-2, характеризується посиленою запальною реакцією з боку усіх систем організму людини, яка може призвести до таких серйозних ускладнень, як ГРДС, сепсис, коагулопатія та смерть у частки пацієнтів.

2. Коагулопатія при COVID-19 характеризується підвищенням рівня фібриногену та D-димеру, помірною тромбоцитопенією та незначним підвищенням ПЧ.

3. У пацієнтів із COVID-19, у яких відмічали ГРДС, значно частіше розвивалися ТЕУ $(11,7 \%)$, переважно ТЕЛА.

4. Основними факторами ризику, що підвищують вірогідність виникнення тромбоемболічних подій, встановлено похилий вік (>60 років), чоловічу стать, артеріальну гіпертензію, цукровий діабет та ожиріння.

5. Для оцінки стану пацієнта, встановлення тяжкості перебігу захворювання та визначення ризику виникнення тромбозу рекомендується проведення таких лабораторних тестів: клінічний аналіз крові з визначенням числа тромбоцитів, коагулограма (ПЧ, АЧТЧ), рівні фібриногену та D-димеру. Особливу увагу клініцисту необхідно звертати на рівень D-димеру, так як високі значення цього показника корелюють з тяжким перебігом захворювання та вищою смертністю.

6. Основним та вагомим маркером тяжкого перебігу COVID-19 $\epsilon$ D-димер. Це один із найбільш ранніх та найпоширеніших лабораторних показників, які відзначають у пацієнтів із COVID-19, високий рівень якого пов'язаний із критичним перебігом та вищою смертністю.

7. Для стандартної стратифікації ризику тромбозу в сучасних умовах необхідно користуватися модифікованою шкалою IMPROVE, яка $\epsilon$ найбільш оптимальною для застосування у паці$\epsilon$ тів із COVID-19 та враховує всі показники для розрахунку ризику тромбоемболії у таких хворих.

8. Для попередження тромбозу у пацієнтів із COVID-19 показане застосування НМГ. Хворим у критичному стані рекомендовано застосування НМГ у профілактичних дозах або половинній терапевтичній дозі у пацієнтів із високим ризиком. Госпіталізованим пацієнтам із середнім ступенем тяжкості захворювання необхідно застосовувати НМГ у профілактичних дозах або фондапаринукс. Не слід проводити рутинну профілактику тромбозу у пацієнтів, які знаходяться на амбулаторному лікуванні.

9. Прийом антикоагулянтів після виписки зі стаціонару може бути розглянутий за наявності високого ризику тромбозу та низького ризику кровотечі.

10. Питання щодо прийому антиагрегантів з метою зниження ризику виникнення тромбозу залишається відкритим та потребує подальшого вивчення.

Конфлікт інтересів: відсутній.

Conflict of interests: the authors declare no conflict of interests.

Список використаної літератури/References:

1. Johns Hopkins University and Medicine (2021) COVID-19 Dashboard by the Center for Systems Science and Engineering (CSSE) at Johns Hopkins University (JHU) (https://coronavirus.jhu.edu/ map.html).

2. Di Minno A., Ambrosino P., Calcaterra I., Di Minno M.N.D. (2020) COVID-19 and Venous Thromboembolism: A Meta-analysis of Literature Studies. Semin. Thromb. Hemost., 46(7): 763-771. doi: 10.1055/s-0040-1715456

3. MeiH., Luo L., HuY.(2020)Thrombocytopenia and thrombosis in hospitalized patients with COVID-19. J. Hematol. Oncol., 13(1): 13-15. doi: 10.1186/s13045-020-01003-z

4. Helms J., Tacquard Ch., Severac F. et al. (2020) High risk of thrombosis in patients with severe SARSCoV-2 infection: a multicenter prospective cohort study. Intensive Care Med., 46(6): 1089-1098. doi: 10.1007/s00134-020-06062-x

5. Ackermann M., Verleden S.E., Kuehnel M. et al. (2020) Pulmonary Vascular Endothelialitis, Thrombosis, and Angiogenesis in Covid-19. N. Engl. J. Med., 383(2): 120-128. doi: 10.1056/NEJMoa2015432

6. Bilaloglu S., Aphinyanaphongs Y., Jones S. et al. (2020) Thrombosis in Hospitalized Patients With COVID-19 in a New York City Health System. JAMA, 324(8): 799-801. doi: 10.1001/ jama.2020.13372

7. Cantador E., Núñez A., Sobrino P. et al. (2020) Incidence and consequences of systemic arterial thrombotic events in COVID-19 patients. J. Thromb. Thrombolysis, 50(3): 543-547. doi: 10.1007/ s11239-020-02176-7.

8. LodigianiC., lapichino G., Carenzo L.etal.(2020)Venous and arterial thromboembolic complications in COVID-19 patients admitted to an academichospital in Milan, Italy.Thromb. Res., 191:9-14. doi: 10.1016/j.thromres.2020.04.024

9. Fajgenbaum D.C., June C.H. (2020) Cytokine Storm. New Eng. J. Med., 383(23): 2255-2273. doi: 10.1056/nejmra2026131 
10. Al-Ani F., Chehade S., Lazo-Langner A. (2020) Thrombosis risk associated with COVID-19 infection. A scoping review. Thromb. Res., 192: 152-160. doi: 10.1016/j.thromres.2020.05.039

11. Helms J., Tacquard C., Severac F. et al. (2020) High risk of thrombosis in patients with severe SARSCoV-2 infection: a multicenter prospective cohort study. Intens. Care Med., 46(6): 1089-1098. doi: 10.1007/s00134-020-06062-x

12. Mestres G., Puigmacià R., Blanco C. et al. (2020) Risk of peripheral arterial thrombosis in COVID-19. J.Vasc. Surg., 72(2): 756-757. doi: 10.1016/j.jvs.2020.04.477

13. Miesbach W., Makris M. (2020) COVID-19: Coagulopathy, Risk of Thrombosis, and the Rationale for Anticoagulation. Clin. Appl. Thromb. Hemost., 26. doi: 10.1177/1076029620938149

14. Holst A.G., Jensen G., PrescottE. (2010) Risk factors for venous thromboembolism: results from the Copenhagen City Heart Study. Circulation, 121(17): 1896-1903. doi: 10.1161/CIRCULATIONAHA.109.921460

15. Benito N., Filella D., Mateo J. et al. (2020) Pulmonary Thrombosis or Embolism in a Large Cohort of Hospitalized Patients With Covid-19. Front. Med. doi: 10.3389/fmed.2020.00557

16. Marcos S.Z., Antelo M.L., Galbete A. etal. (2020) Infection and thrombosis associated with COVID-19: Possible role of the ABO blood group. Med. Clin. (Engl. Ed.), 155(8): 340-343. doi: 10.1016/j. medcle.2020.06.013

17. Shibabaw T. (2020) Inflammatory Cytokine: IL-17A Signaling Pathway in Patients Present with COVID-19 and Current Treatment Strategy. J. Inflamm. Res., 13: 673-680. doi: 10.2147/JIR. S278335

18. Nasonov E., Samsonov M. (2020) The role of Interleukin 6 inhibitors in therapy of severe COVID-19. Biomed. Pharmacother., 131: 110698. doi: 10.1016/j.biopha.2020.110698

19. Dong Sh., Pei B., Xie W. et al. (2020) Anticardiolipin antibody and anti- $\beta_{2}$ glycoprotein I antibody are potential risk markers of ischaemic stroke in Chinese adults. Rheumatology (0xford), 59(8): 1834-1841. doi: 10.1093/rheumatology/kez551

20. Harzallahl., Debliquis A., Drénou B. (2020) Lupus anticoagulant is frequent in patients with Covid-19. J. Thromb. Haemost., 18(8): 2064-2065. doi: 10.1111/jth.14867

21. Guan W.J., Ni Z.Y., HuY. (2020) Clinical characteristics of coronavirus disease 2019 in China. N. Engl. J. Med., 382: 1708-1720.

22. Tang N., Li D., Wang X., Sun Z. (2020) Abnormal coagulation parameters are associated with poor prognosis in patients with novel coronavirus pneumonia. J. Thromb. Haemost., 18(4): 844-847. doi: $10.1111 /$ jth. 14768

23. Spyropoulos A.C., Levy J.H., Ageno W. et al. (2020) Scientific and Standardization Committee communication: Clinical guidance on the diagnosis, prevention, and treatment of venous thromboembolism in hospitalized patients with COVID-19.J.Thromb. Haemost., 18(8):1859-1865. doi:10.1111/ jth.14929

24. White D.,MacDonald S., Bull T. et al. (2020) Heparin resistance in COVID-19 patients in the intensive care unit. J. Thromb. Thrombolysis, 50(2): 287-291. doi: 10.1007/s11239-020-02145-0

25. Cuker A., Peyvandi F. (2021) COVID-19: Hypercoagulability (https://www.uptodate.com/contents/

26. Yavelov I.S., Drapkina 0.M. (2020) COVID-19: Hemostatic parameters and specifics of antithrombotic treatment. Cardiovasc. Ther. Prevent., 19(3):2571. doi: 10.15829/1728-8800-2020-2571. (In Rus.).

27. https://clinicaltrials.gov/ct2/show/NCT01583218

28. Revel M.-P., Parkar A.P., Prosch H. et al. (2020) COVID-19 patients and the radiology department - advice from the European Society of Radiology (ESR) and the European Society of Thoracic Imaging (ESTI). Eur. Radiol. (https://doi.org/10.1007/s00330-020-06865-y).

29. ESC (2020) ESC Guidance for the Diagnosis and Management of CV Disease during the COVID-19 Pandemic (www.escardio.org/Education/COVID-19-and-Cardiology/ESC-COVID-19-Guidance).

30. Piazza G., Morrow D.A. (2020) Diagnosis, Management, and Pathophysiology of Arterial andVenous Thrombosis in COVID-19 (https://jamanetwork.com/journals/jama/fullarticle/2773516). coronavirus-disease-2019-covid-19-hypercoagulability).

31. Lemos A.C.B., Santo D.A.D.E., Salvetti M.C. et al. (2020) Therapeutic versus prophylactic anticoagulation for severe COVID-19: A randomized phase II clinical trial (HESACOVID). Thromb. Res., 196: 359-366.

32. Tang N., Bai H., Chen X. et al. (2020) Anticoagulant treatment is associated with decreased mortality (https://onlinelibrary.wiley.com/doi/pdf/10.1111/jth.14817).

33. Ranucci M., Ballotta A., Di Dedda U. et al. (2020) The procoagulant pattern of patients with COVID-19 acute respiratory distress syn-drome (https://onlinelibrary.wiley.com/doi/10.1111/ jth.14854).

34. NIH (2020) Coronavirus Disease 2019 (COVID-19) Treatment Guidelines (https://www.covid19treatmentguidelines.nih.gov/).

35. Roberts L.N., Whyte M.B., Georgiou L. et al. (2020) Postdischarge venous thromboembolism following hospital admission with COVID-19. Thromb. Hemost., 136(11): 1347-1350.

36. Patell R., Bogue Th., Koshy A. et al. (2020) Postdischarge thrombosis and hemorrhage in patients with COVID-19. Blood, 136(11): 1342-1346. doi: 10.1182/blood.2020007938

37. https://www.evms.edu/media/evms_public/departments/internal_medicine/Marik-CovidProtocol-Summary.pdf

38. Chow J.H., Khanna A.K., Kethireddy Sh. et al. (2021) Aspirin Use Is Associated With Decreased MechanicalVentilation, Intensive CareUnit Admission, and In-Hospital Mortality in Hospitalized Patients With Coronavirus Disease 2019. Anesth. Analg., 132(4): 930-941. doi: 10.1213/ ANE.0000000000005292

39. DiNicolantonioa J.J., Barroso-Arandab J. (2020) Harnessing adenosine A2A receptors as a strategy for suppressing the lung inflammation and thrombotic complications of COVID-19: Potential of pentoxifylline and dipyridamole. Med. Hypotheses., 143: 110051. doi: 10.1016/j. mehy.2020.110051

\section{Risk factors and prevention of thrombosis in patients with COVID-19} O.O. Khaniukov, L.V. Sapozhnychenko, O.S. Kalashnikova, O.V. Somilo, Eu.O. Okhotnik

State Institution «Dnipropetrovsk medical academy of the Ministry of Health of Ukraine», Dnipro, Ukraine

Abstract. The article presents a review of the literature on the study of risk factors and prevention of thrombosis in patients with COVID-19. COVID-19 coagulopathy is characterized by increased levels of fibrinogen and D-dimer, moderate thrombocytopenia and slight increase of prothrombin time. The main risk factors that increase the probability of thromboembolic events are old age (>60 years), male gender, hypertension, diabetes and obesity. For standard stratification of thrombosis risk in modern conditions, it is necessary to use a modified IMPROVE scale, which is the most optimal for use in patients with COVID-19 and takes into account all indicators for calculating the risk of thromboembolism in such patients. The use of low molecular weight heparins is indicated to prevent thrombosis in patients with COVID-19. Taking anticoagulants after discharge from the hospital may be considered if there is a high risk of thrombosis and a low risk of bleeding. The question of taking antiplatelet agents to reduce the risk of thrombosis remains open and needs further study.

Key words: COVID-19, thrombosis, risk factors, prophylaxis, scale of risks.

\section{Відомості про авторів:}

Ханюков Олексій Олександрович — доктор медичних наук, професор, ДЗ «Дніпропетровська медична академія Міністерства охорони здоров'я України», Дніпро, Україна.

Сапожниченко Людмила Володимирівна — кандидат медичних наук, доцент, ДЗ «Дніпропетровська медична академія Міністерства охорони здоров'я України», Дніпро, Україна.

Калашникова Оксана Сергеевна — кандидат медичних наук, асистент, ДЗ «Дніпропетровська медична академія Міністерства охорони здоров'я України», Дніпро, Україна

Соміло Ольга Владиславівна — асистент, ДЗ «Дніпропетровська медична академія Міністерства охорони здоров'я України», Дніпро, Україна.

Охотнік Євгеній Олександрович — студент VI курсу, ДЗ «Дніпропетровська медична академія Мiністерства охорони здоров'я України», Дніпро, Україна.

Адреса для кореспонденції:

Сапожниченко Людмила Володимирівна

49044, Дніпро, вул. В. Вернадського, 9

E-mail:s.lyuda@i.ua

\section{Information about the authors:}

Khaniukov Oleksiy 0. - PhD in medicine, professor, SI «Dnepropetrovsk Medical Academy of the Ministry of Health of Ukraine», Dnipro, Ukraine.

Sapozhnychenko Ludmila V. — PhD in medicine, associate professor, SI «Dnepropetrovsk Medical Academy of the Ministry of Health of Ukraine», Dnipro, Ukraine.

Kalashnikova Oxsana S. — PhD, assistant, SI «Dnepropetrovsk Medical Academy of the Ministry of Health of Ukraine», Dnipro, Ukraine.

Somilo Olga V. - assistant, SI «Dnepropetrovsk Medical Academy of the Ministry of Health of Ukraine», Dnipro, Ukraine.

Okhotnik Eugene 0. - 6th year student, SI «Dnepropetrovsk Medical Academy of the Ministry of Health of Ukraine», Dnipro, Ukraine.

\section{Address for correspondence:}

Ludmila Sapozhnychenko

49044, Dnipro, V. Vernadsky str., 9

E-mail: s.lyuda@i.ua 